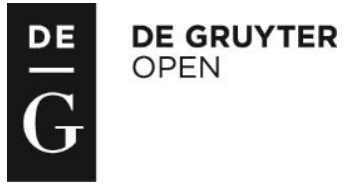

*Daniela Maria Marțole

Faculty of Letters and Communication Sciences,

Ştefan cel Mare University of Suceava,

13 Universităţii Street, 720229 Suceava, Romania

email: danielamartole@yahoo.com

\title{
ETHNOCENTRIC TENDENCIES IN THE ROMANIAN TRANSLATIONS OF MACBETH
}

\begin{abstract}
Starting from Venuti's binary classification of translations into ethnocentric and foreignizing this paper focuses on the factors that trigger ethnocentric attitudes in the translation of the play Macbeth in Romanian. Counterbalancing the extremely neologist tendencies at the end of the $19^{\text {th }}$ century and the beginning of the $20^{\text {th }}$ century, exemplified in Ștefan Băjescu's translation, most of the $20^{\text {th }}$ century translators prove an inclination towards the use of local, ethnic elements, that should revive the national culture and language, the integrity of which was threatened by foreign elements. Ion Vinea's translation, that was the canonical Romanian version for more than half a century, is analysed in the paper as the representative of the ethnocentric camp. Apart from the spontaneous reactions that are generally ruled by the laws of language change, other factors that lead to the fostering of ethnocentric views are the communist regime's constrictive ideology and, at the micro level, the translator's own linguistic and cultural perception.
\end{abstract}

Keywords: Macbeth, translation, ethnocentric, Romanian Communism

In my research I analysed the language of the Romanian versions of the play Macbeth against the social, cultural and political backgrounds, in order to understand the impact of extralinguistic reality on the lexical choices of the translators. If, as Edward Sapir puts it, "language is a guide to social reality" (in Mandelbaum, 1985:162), when read and analysed chronologically, the Romanian translations of the tragedy Macbeth may serve as linguistic guides to some major social, political and cultural changes in $19^{\text {th }}$ and $20^{\text {th }}$ century Romania. The translation history of the play covers a time span of 160 years, period of critical importance for the Romanian language. Significant historical events contained in this time frame, such as the merger of the two historical principalities of Wallachia and Moldova in 1859 and the unification of Greater Romania in 1918, had a huge impact on the Romanian language and also on the emergent linguistic community.

Forty years before the publication of the first translation of the play Macbeth in Romanian, in 1813, the German theologian and philosopher Friederich Schleiermacher delivered, to the Royal Academy of Science in Berlin, a lecure entitled "On the different methods of Translating", in which he clearly formulated two translation principles: "Either the translator leaves the author in peace, as much as possible, and moves the reader toward him. Or he leaves the reader in peace, and moves the author toward him" (cited in Lefevere, 1992:149). Almost two hundred years later, Lawrence Venuti,

\footnotetext{
* Dr. Daniela Maria Marțole is Lecturer in English at the Department of Foreign Studies, Ștefan cel Mare University of Suceava, where she teaches English language and linguistics and translation classes. Her research is mainly focused on the translation of Shakespeare's play, Macbeth, into Romanian. She is particularly interested in the way in which cultural, social and political factors influence the evolution of the Romanian language and the reflection of such changes in the language of the translations. Other fields of interest are: Discourse Analysis, Cultural Studies and Victorian Literature.
} 
translator and translation theorist, reformulates Schleiermacher's theory, claiming that translators should "choose between a domesticating method, an ethnocentric reduction of the foreign text to target language cultural values, bringing the author back home, and a foreignizing method, an ethnodeviant pressure on those values to register the linguistic and cultural difference of the foreign text, sending the reader abroad" (Venuti, 1995:20).

A cursory lexical analysis according to the translation theories above mentioned sent the existing translations of the play ${ }^{1}$ in two imbalanced groups, the two $19^{\text {th }}$ century translations qualifying as foreignizing texts ${ }^{2}$, inviting the reader into a cosmopolitan linguistic space, whereas the five $20^{\text {th }}$ century translations entered the ethnocentric camp. The $21^{\text {st }}$ century translations make distinct cases that should be discussed separately. In the present article I will focus mainly on Băjescu's and Vinea's translations.

\begin{tabular}{|c|c|c|c|}
\hline $\begin{array}{l}\text { A.The raven himself is } \\
\text { hoarse } \\
\text { That croaks the fatal } \\
\text { entrance of Duncan } \\
\text { Under my battlements. } \\
\text { Come, you spirits } \\
\text { That tend on mortal } \\
\text { thoughts, unsex me } \\
\text { here, } \\
\text { And fill me from the } \\
\text { crown to the toe, top-ful } \\
\text { Of direst cruelty(I.5:37- } \\
42) \text {. }\end{array}$ & $\begin{array}{l}\text { A.Oui, pleine de douceur } \\
\text { et de charme serait la } \\
\text { voix de corbeau même }{ }^{3} \text {, } \\
\text { qui par ses croassements } \\
\text { m'annoncerait l'entrée } \\
\text { fatale de Duncan sous les } \\
\text { lambris de mon château. } \\
\text { Venez tous, esprits } \\
\text { infernaux, qui inspirez } \\
\text { les pensées homicides; } \\
\text { dépouillez-moi de mon } \\
\text { sexe en cet instant et } \\
\text { remplissez-moi toute } \\
\text { entière, tête et coeur, } \\
\text { d'une cruauté pure et } \\
\text { sans mélange de pitié. } \\
\text { (H. Meyer, 1836) } \\
\text { B. ...lorsque je songe } \\
\text { que vous pouvez } \\
\text { contempler pareils } \\
\text { objets et conserver le } \\
\text { même incarnat sur vos } \\
\text { joues, tandis que les } \\
\text { mienne sont toutes } \\
\text { pâles de frayor. } \\
\text { (H. Meyer, 1836) }\end{array}$ & $\begin{array}{l}\text { A. Da, plină de dulceață și de } \\
\text { grație ar fi vocea chiar a } \\
\text { corbului, care prin } \\
\text { croncănirea sa mi-ar anunța } \\
\text { fatala intrare a lui Duncan } \\
\text { sub luxosul acoperământ al } \\
\text { castelului meu. - Veniți cu } \\
\text { toate, spirite infernale, care } \\
\text { inspirați cugetele } \\
\text { omucide,[Come you all, } \\
\text { infernal spirits that inspire } \\
\text { homicidal cogitations] veniți, } \\
\text { ridicați-mi sexul in acest } \\
\text { moment, şi umpleți-mi tot, } \\
\text { capul și inima, d'o cruzime } \\
\text { adevărată și fără cea mai } \\
\text { mică caritate. } \\
\text { (Ș. Băjescu, 1850) } \\
\text { B. ...când cuget că o să } \\
\text { puteţi contempla nişte } \\
\text { assemine objete şi a vă } \\
\text { conserva carmeni } \\
\text { incarnatului vostru, când } \\
\text { eu şi sunt palid de frică } \\
\text { [...when I cogitate that you } \\
\text { will be able to contemplate } \\
\text { some such objects and to } \\
\text { preserve the carmines of } \\
\text { your incarnadine when I am } \\
\text { pale with fear] } \\
\text { (Ș. Băjescu, 1850) }\end{array}$ & $\begin{array}{l}\text { A. Mai să-şi dea duhul de } \\
\text { țipat şi corbul } \\
\text { Vestind morțiu intrarea lui } \\
\text { Duncan, } \\
\text { Pe poarta mea, sub zidurile } \\
\text { astea. } \\
\text { Veniţi strigoi care-ndemnaţi la } \\
\text { crimă } \\
\text { [Come, ghosts that inspire } \\
\text { murder], } \\
\text { Luaţi-mi feminitatea, umpleți- } \\
\text { mă } \\
\text { Din cap până-n picioare de } \\
\text { cruzime } \\
\text { (H. Gârbea, 2014) } \\
\text { B....când văd că tu te uiţi } \\
\text { La lucruri de-astea şi obrajii } \\
\text { ți-s } \\
\text { Îmbujorați când eu sunt alb } \\
\text { de frică. } \\
\text { [... When I see that you } \\
\text { look/At such things and your } \\
\text { cheeks are/Rosy when I am } \\
\text { white with fear ] } \\
\text { (H. Gârbea, 2014) }\end{array}$ \\
\hline
\end{tabular}

${ }^{1}$ The Romanian translators of the play, in chronological order, are: 1850 - Ștefan Băjescu (prose translation in Cyrillic alphabet), 1864, 1886 - P. P. Carp, 1912 - Const. A Ștefănescu (prose translation), 1922 - Adolphe Stern, 1925 - Mihail Dragomirescu, 1936 - Vasile Demetrius (prose translation), 1945 - Dragoș Protopopescu (translation in manuscript), 1945- Ion Sava (stage translation), 1957 - Ion Vinea, 2000 - D. A. Lăzărescu, 2014 - Horia Gârbea; with the excepion of the 3 prose translations mentioned, all the other translations are in verse.

${ }^{2}$ Some researchers may consider Carp's text should enter the ethnocentric camp, as it contains a plethora of regional terms, strictly specific to Moldova, the former Romanian pricipality. It is true that, being a Germanophil, as most of the intellectuals that formed the cultural group Junimea, Carp does not follow the analytical, French model and, as a consequence, the number of unadapted words/phrases is rather small, as compared to Băjescu's text. Nonetheless, Carp was blamed for the use of barbarisms by both his contemporaries and the following generations, therefore, for the present stage of my research, I will include him in Băjescu s camp.

${ }^{3}$ The printing in my copy of Meyer's book is not very clear, so in the case of même, tête, château, pâle, I used the modern ortography. 
Băjescu's translation, published in 1850 in the transitional Cyrillic alphabet with numerous Latin elements, undoubtedly reflects the Latinist tendency of the age and the tremendous influence of the French intermediary text. Once the Romanians acknowledged the Latin roots of their language, the French culture became a natural and perpetual source of inspiration and it provided a model that embodied the Romanians' hopes for the fulfillment of their own cultural and linguistic aspirations. Most of the $19^{\text {th }}$ and $20^{\text {th }}$ century translators use French texts, if not as their intermediary sources, at least as tertium comparationis.

The translator was overwhelmed by the source text that he translated with literal fidelity, sometimes simply borrowing French terms that he only slightly adapted, morphologically, to the Romanian language. The French source text was a subject of controversy along the years and, in Dicţionarul literaturii române de la origini până la 1900 [The Dictionary of Romanian Literature from its Origins to 1900], the information given is erroneous, the authors claiming Băjescu translated Duci's text when in fact, Băjescu used Horace Meyer's edition of Leturnoeur's translation. The two editions are only different in what concerns some upgrading that Meyer performed in Leturneur's text, such as the replacement of some verb forms or the change of the symbol \& with et "and". Another difference is the use of endnotes in Meyer's (and Băjescu's text), as compared to Letourneur's text, where footnotes are employed. Meyer respects Letourneur's rewriting of the scenes, for instance fragment A in the table below is in act one, scene five, in Shakespeare's text, while in Meyer's and Băjescu's texts is in scene 8 .

Although, for the specialised reader, the language of the translation can exert some kind of fascination, the process of reading is tedious, a rather awkward characteristic for a text that seems to have been used as a stage script for Halepliu's actors between1850-1852. When compared with the most recent translation, Băjescu's text sounds artificial and pretentious and many of the words he used (that were finally adapted to Romanian) are still in dictionaries of neologisms. Băjescu's translation is the result of a huge effort to rethink the Romanian standard language according to the tendencies of the time. We can't ignore the translator's attempt to enrich the language by the use of a large number of neologisms of which some made it through to present day Romanian, although, excessively used, they would give speech an unnatural resonance even today, as the examples clearly show. More than that, as shown by the translation of the verb unsex, the uncritical employment of the French paraphrase may get comic effects, as ridicați-mi sexul can have various meanings: "remove my sex", "elevate my sex", "pick up my sex" and it is far from getting the dramatic tension in Shakespeare's play. In the French text, dépouillez-moi de mon sexe means "dispossess me of my sex/strip off my sex” and the translator must have probably thought of portraying it as an action of shedding a skin, or removing a piece of clothing. Unfortunately, faithful as he is to the source text, the translator obscures the original meanings of the play. In contrast, in spite of the obvious difficulty of the passage, Horia Gârbea's wonderful translation of the same verb luați-mi feminitatea (take away my femininity), thoroughly respects the meaning of the word, defined in the World English Dictionary, as ,literary chiefly to deprive (a person) of the attributes of his or her sex, esp. to make a woman more callous" and paves the way to modern critical interpretations of Lady Macbeth's character.

In text B, in the table above, Băjescu completely misunderstands the French text. Incarnat is a French adjective used for "bright red" that the Romanian translator mistakes for a noun related to the noun carne "flesh" and he uses it as an equivalent for joue "cheek". In order to cover the translation for "the natural ruby", he then uses the word carmeni, probably an awkward plural form of the noun carmin, of French extraction, that is still in use in Romania today and has the meaning of "bright red". By comparison, Gârbea's translation, obrajii ți-s îmbujorați [your cheeks are rosy], makes use of a usual Romanian collocation, the rosy colour of the cheeks being frequently associated with the colour of the peony, bujor, hence the verb a imbujora "(especially used for the face) to turn into the colour of the peony".

The back translations of the fragments in bold or italics in both A and B show that the language employed by Bajescu is artificial and strange, loaded with neologisms that will sound strange in every day speech and even more so on stage. Veniți strigoi care-ndemnați la crimă [Come, ghosts that inspire murder] in Gârbea's text may not sound as poetical as Shakespeare meant it, but it is certainly more easily understood and pronounced than Veniți cu toate, spirite infernale, care inspirați cugetele omucide [Come you all, infernal spirits that inspire homicidal cogitations]. The 
adjective oтисіd "homicidal", for instance, is still a neologism and it is rarely used; the noun form, omucidere "homicide" is mainly restricted to legal use.

As one can see, most of the words in the list below have an English counterpart of French extraction but in Romanian, those who survived, have either different forms, or different meanings:

orage/ tempeste "tempests", oragios "tempestuous", confienţă "confidence", dignitate "dignity", chestiune "question", companion, nuvellă "piece of news", caritate "charity", consiliu "counsel", audacie "audacity", uvragiu "work", objet, abundanţă "abundance", present "gift", veritate "truth", tapagiu "noise", culpabil "guilty", guerră "war", megere "wicked women, shrews", omage "homage", precipiţiu "precipice", parolă "word", convivi "guests", langagiu "language", circonstanţă "circumstance", kambellani "chamberlains", consinge "blood relative", a se fatiga "to fatigue oneself" a se fini "to end", a curona "to crown", a confia "to confide", a mepriza "to despise", a devina "to divine/foretell".

The translator's innovative work is, however, not to be minimised and overlooked. As it was among the first translators of Shakespeare's work in Romanian, Băjescu had a hard time managing his relationship with the French text. On top of that, the cultural and linguistic environment of the age fostered such foreignizing attitudes that were more and more pregnantly found in national literature. An interesting phenomenon occurs in the witches' lines, which Băjescu translates in rhyming verse, where the constriction of form no longer allows for the indiscriminate borrowing of French words. The language is much more similar to the one we speak today and even younger generations might take pleasure in the musicality of the fragments:

Broscoi care, într'al lunei spaţiu iute trecător/ Adormit şi zi şi noapte suppt o piatră îngheţată,/ Te ai umflat încet cu'ncetul d'un venin prăpăditor/mergi şi intră tu'nainte în căldarea fermecată (Băjescu, 1850:85).

Să'ndoim, să'ndoim îngrijirea şi lucrarea/Să lăsăm să arză focul şi să fiarbă şi căldarea (ibidem).

Să punem să se recească într'un sânge de maimuţă/Şi atunci al nostru farmec e'ntărit de aghiuţă (Băjescu, 1850:86).

The contemporary reader's objections to Băjescu's text only reduplicate the negative reactions of the $19^{\text {th }}$ century reader to non-translated texts, especially poetry, as the massive import of neological words from both French and Italian resulted in an unconciliatory breach between written texts and spoken language. Some intellectuals who, up to that moment, had embraced what we would call today Eurocentric attitudes that integrated ideas of progress, linguistic innovation and concepts of alterity, began to underline the detrimental external influences, as a consequence of their perpetual concern with ethnic hybridity and linguistic degeneration. ${ }^{4}$ When speaking of emergent nation states, historian Eric Hobsbawm underlines the fact that "ethnicity and language became the central, increasingly the decisive or even the only criteria of potential nationhood" (Hobsbawm, 2000: 102). Consequently, Romanian intellectuals started to focus on the awakening of the national consciousness among both uneducated and educated strata and on the creation of a standardized language, comprehensible to all, an important desiderate made even more stringent after the merger of the two historical pricipalities of Wallachia and Moldova.

Analysing the roots of nationalism, Professor A. D. Smith enumerates the three antinomies that are generally proposed by researchers of nations: traditional (genetic) vs. constructed, old vs. modern and cultural vs. political, and comments upon the debate generated around the last two: "By the early twentieth century, the lines of division between the 'objectivists' who stressed the role of culture, and more especially language, in the definition and formation of nations, and the 'subjectivists' for whom nations are formed by popular will and political action, were well entrenched in European historiograpgy"(Smith, 2003:170). In Romania, the two approaches to nation and nationalism seem to have manifested simultaneously in the second half of the $19^{\text {th }}$ century, or they simply succeeded one

\footnotetext{
4 see Titu Maiorescu, O cercetare critică asupra poeziei române de la 1867 [A Critical Approach to the Romanian Poetry in 1867], or Nicolae Iorga, Lupta pentru limba românească [The Fight for the Romanian Language], in 1906.
} 
after the other at a very rapid pace. The ones who admitted the superiority and the historical existence of the French culture wanted to find genealogical connections to it and, if possible, transfer it on Romanian ground. This could very easily be accomplished through language, and Ștefan Băjescu's translation is just one of the countless examples of such texts, many of them non-translated. At the same time, Romanians felt that, being an emergent nation, they needed a language that would speak to/for them all. As Smith remarks, "language and linguistic politics were the main factors in creating national consciousness in modern European new nations" (idem: 173).

Therefore, the highly innovative cultural movements that had shattered the Romanian language in the second half of the $19^{\text {th }}$ century were slowly replaced by a populist nationalism that preached for the reinstatement of the previously marginal, rural and regional linguistic elements that would have allegedly helped create an autochthonous and authentically Romanian model. All this cultural unrest is amply reflected in all $20^{\text {th }}$ century translations of the play Macbeth, beginning with Constantin Ştefanescu's prose translation in 1912 and ending with Ion Vinea's text, the canonical Romanian version for more than fifty years. In contrast with the foreignizing, innovative texts of the previous century, the $20^{\text {th }}$ century translations include a plethora of old and regional terms, mirroring the nontranslated literature that celebrated the uniqueness of the national character. In his work Sămănătorism, Poporanism, Criticism, Mihail Dragomirescu, one of the translators of the play who, among other things, was a literary theorist, claimed that the cultural stage in the history of the Romanian spirit that covered the period between 1920 and 1930 "se distinge printr-o mişcare culturală şi printr-un avânt spre lumină fără precedent în atmosfera vieţii noastre publice; prin afirmarea prereminenţei noastre artistice şi literare, atât în ţară cât şi în streinătate[...] printr-o năzuinţă necunoscută până acum spre creaţiune originală şi literară, liberă de cătuşele streinătăţii, în toate direcţiile"5(Dragomirescu, 1934:10). The need for Romanians' artistic preeminence inside the country has to do with the change in demographic distribution and the phenomenon of ethnic dilution that resulted from the unification of Greater Romania. As historian Lucian Boia remarks: "presiunea străinilor, din afară sau din interior, reală până la un punct, dar hiperbolizată în imaginarul național, a generat complexul de cetate asediată, foarte tipic pentru mentalitatea românească a ultimelor două secole. Istoria românilor este înțeleasă într-o manieră strict conflictuală, ca o luptă continuă purtată pentru supraviețuire etnică și statală"’6(Boia, 1997: 255).

A good example of such conflictual energies is the case of Adolph Stern, another translator of the play, viewed both as an external and as an internal foreigner, frequently criticised not only for his ethnocentric, localizing tendencies but also for his supposedly innate incapacity to properly understand and use the Romanian language, due to his Jewish descent. ${ }^{7}$ One of the stringent priorities of the Romanian intellectuals was to become more visible in the cultural and urban life of the country, hence the breach between the peasants and the educated elite that covered all life aspects, including language. As a consequence, writers and translators started using regional and more archaic terms, in order to bridge this gap that was disruptive of Romanian unity. If we look at this small selection of words of Turkish and Slavic origin, that populated the texts of the 20th century translations, it is no longer possible to relate them to English as we did with the words in the previous list:

taman, adv. <Turkish tamam, "especially, exactly" barem adv. < Serbian or Bulgarian, barem, "at least"şart, $n$. < Turkish șart "tradition, usage, rule, convention, "bogdaproste int./n. < Bulgarian bog da prosti "May God forgive the dead"mendre "whims, caprices" plural noun of unknown extraction; a-și face mendrele (literally, "to do one's whims"), har n. < old Slavic chari, "(divine)grace,

\footnotetext{
5 "distinguishes from other periods by a cultural movement and by an impetus towards light that are unprecedented in the environment of our public life; by the assertion of our artistic and literary preeminence, both in our country and abroad, through a sense of purpose, unknown to us until now, towards an original literary creation, freed form the handcuffs of foreign elements, in all directions."(my translation, italics in original).

6 'the pressure of the foreigners, from outside and from within, real up to a point but hyperbolized by the national imaginary, generated the complex of „citadel under siege”, so typical for the Romanian. mentality of the past two centuries. The history of Romanians is understood in a strictly conflictual manner, as an ongoing strggle for ethnic and statal survival"(my translation)

${ }^{7}$ I delt with Stern's case in a previous article, Ethnic Bias in the Reception of Adolph Stern's Translations of Hamlet and Macbeth, published in Messages, Sages and Ages, Volume 2, No. 1, 2015, 38-46.
} 
talent"nur n. < Turkish nur "sex appeal" opincă n. < Bulgarian opinka, "peasant leather footwear fixed by the ankle with laces wound over textile ankle wraps" bahorniță (< Serbian. bahornica) regional form for "hag"; ostrov (< Old Slavic ostrovŭ) "island"; pristav ( $<$ O. Slavic pristavŭ) "messenger" cobitor (< Serbian. Kobiti; Bulgarian kobja) "of ill omen"; hâd (< Ukrainian hyd) "ugly"; a vecui (< O.Slavic věkǔ) "to live (with somebody)"; pricaznică (<Slavic prokažati) "deadly"; coleașă $(<$ Serbian kulijez, Bulgarian .kulijaša) "polenta"; nădejdi ( < O.Slavic nadežda) "hopes"; horbotă (pol. forbot) "regional term for lace"; triște(< O. Slavic .sŭrenšta, srešta) "fate"; cruşit ( < Ukrainian krušyty) "red with blood"; izvod (sl. izvodŭ) "list, file"; hal (<Turkish hal) "bad state", şaică (<Turkish şaika) olăcar (< Turkish ulak+ar).

The same programmatic stance seems to control Ion Vinea's approach to the Romanian Language. Vinea was a poet of the avant-guarde and a promoter of modernist values. Although a prolific writer, he was criticised by his contemporaries for the rather moderate spirit displayed in his work, in stark contrast to the audacity he generally showed in the theoretical manifestos published in the literary journals of the time. The lexical choices in translation, published in 1957, reflect, on the one hand, the anti-neologist tendencies of his time and, on the other hand, the poet-translator's own agenda of reintegration of local values in the individual and general poetic sensitivity. His critical beliefs are prefigured by a cultural manifesto that he published in the journal "Punct" [Fullstop], in the thirties, whence we reproduce a fragment: "Metrou, metronom, mecanic, constructiv: nickel, express, radium, telefon, T.F.F., cablu, ascensor, termometru, bitum, calcul, integral, vermouth, viteză, paşaport, radiator; arc voltaic, pneumatic, motor, alcool, turbină etc. ${ }^{8}-1$ 'opinion courante est que rien qu'en employant un vocabulaire de contremaître d'usine, en guise de paroles en liberté, on devient pour cela, poéte moderne...C'est une revolution de lexique. C'est une conception de garçon-coiffeur autodidacte. A quand la révolution de la sensibilité,- la vraie?" (Vinea, cited in Morar, 2003:41). Vinea speaks against the burdening avalanche of neologisms that invaded the Romanian language, at the expense of older terms that, already at home in the natural production of language, were much more appropriate for artistic use. However, as compared, for instance, with Dragomirescu's translation, published thirty years before, in Vinea's text, regional and archaic terms have a low frequency. Faithful to his creed, Vinea proves even more moderate in the use of neologisms and their list is restricted to the following: paricid "parricid", sperjur "perjury" and tiran "tyrant".

\begin{tabular}{|c|c|c|}
\hline $\begin{array}{l}\text { Let us rather } \\
\text { Hold fast the mortal sword: } \\
\text { and like good men } \\
\text { Bestride our down-fall } \\
\text { birthdom:each new morn, } \\
\text { New widows howl, new orphans } \\
\text { cry, new sorrows } \\
\text { Strike heaven on the face, that it } \\
\text { resounds } \\
\text { As if it felt with Scotland, } \\
\text { and yelled out } \\
\text { Like syllable of dolour. } \\
\text { (IV.3, 2-8) }\end{array}$ & $\begin{array}{l}\text { Mai bine } \\
\text { Să tragem spada morții ca } \\
\text { ostași[Let us rather pull out the } \\
\text { death sword as soldiers],/ } \\
\text { Să punem iar în șa căzuta patrie } \\
\text { [Let us put back in the saddle } \\
\text { the fallen fatherland]/ } \\
\text { Căci zi de zi noi văduve și- } \\
\text { orfani/Bocesc și gem, și alte } \\
\text { suferinți/Dau palme cerului, } \\
\text { stârnind ecou/Ce pare-a plânge } \\
\text { Scoția și-ai îngâna /Suspinele } \\
\text { de dor. [that seems to mourn } \\
\text { Scotland and to echo her } \\
\text { longing sighs] } \\
\text { (Aurel Vasilescu, 1962) }\end{array}$ & $\begin{array}{l}\text { Mai bine, } \\
\text { Să tragem cruntul paloș vitejește } \\
\text { [Let us rather bravely pull out the } \\
\text { ferocious broadsword ],/Străbunul } \\
\text { nostru drept să-1 apărăm, [our } \\
\text { ancestral right to defend]/Că zi cu } \\
\text { zi, și-alt geamăt de vădană,/ } \\
\text { Și-alt plâns de-orfan, și alte } \\
\text { suferinț/Lovesc în față cerul ce } \\
\text { răsună/Și-ngână parcă însuși } \\
\text { glasul țării,/Urlându-și vaietele } \\
\text { de durere. [and seems to echo the } \\
\text { very voice of the country/Howling } \\
\text { her cries of pain] } \\
\text { (I. Vinea, 1957) }\end{array}$ \\
\hline
\end{tabular}

Romanian scholars who analysed Shakespeare in translation have underlined the way in which the communist regime had confiscated Shakespeare's work for ideological purposes, imposing the use of a large number of Slavic words, to show solidarity with the communist Soviet Union, and

\footnotetext{
8 "Subway, metronome, mechanic, constructive: nickel, express, radium, telephone, wireless telegraphy, cable, elevator, thermomiter, bitumen, calculus, integral, vermouth, speed, passport, radiator; voltaic arc, pneumatic, engine, alcohol, turbine engine, etc[...]". (my translation)
} 
eradicating any religious hint. Despite the fact that Vinea's translation was diachronically the first to be published after the installation of the communist regime, there is no lexical evidence in the text to prove such an attempt in the case his translation of Macbeth. Not only had Vinea preserved the religious vocabulary, but there were no fragments in the text I could possibly link to the communist ideology. It was a poet, translating another poet, rather than a playwright, but beautifully, up to the level of alliteration. "Great tyranny, lay though thy basis sure", Macduff says in act four, and Vinea translates $\boldsymbol{T}$ e-ntemeiază trainic, tiranie.

However, the play Macbeth was not altogether free form the hinges of ideological coercion. In Virgil Petrovici's study on Ion Sava's Macbeth cu măști [Macbeth with masks], I have come across a fragment from Aurel Vasilescu's translation for Mihai Berechet's stage production in 1962.

In his memoires entitled Nouă caiete albastre (Nine Blue Notebooks) Mihai Berechet remembers that Zaharia Stancu, who was then the director of The National Theatre, had made the staging of Macbeth contingent on Aurel Vasilescu's translation, which he had commissioned and paid with good money (Berechet, 1983:2013). If we compare Vasilescu's fragment with Vinea's version, we can see that Vinea sets Shakespeare's play in an idealised, potentially medieval period, marked by acts of chivalric bravery, whereas Vasilescu, using a communist cliche, points to a more recent past, the presence of the soldiers alluding to an implied enemy threatening to the fatherland that will inflame the communist immagination and discourse through the entire communist period. The translation of good men by ostași [soldiers] reflects the already established perception of those belonging to the coercive structures in the state as important, necessary and superior.

One might incline to believe that, being more difficult to stage, given the heavy political load the play carried, it was less exposed to censorship than other plays, but the minute it threatened to leave the shelf and to enter the public space, its meanings had to be subsumed to the ideological needs of the age. Historian Lucian Boia asserts that the period around 1960 can be considered the brightest period of the communist regime (Boia, 2016:98). The need for the restoring of Romanian tradition and cultural values called for the inclusion, in the system, of the intellectuals who, up until then, had been reluctant to the communist ideology and had paid for it in the communist prisons. Released from prison, they had the opportunity to publish their writings, contributing to the cultural evolution of the country and serving the best interests of the regime. Vinea, for instance, says Berechet, was among the initial choices for the translation of the play, as he had been "recently rehabilitated" (Berechet, 1983:212). The fact that Vasilescu undertranslates "syllable of dolour" with suspine de dor [longing sighs] completely depletes the Romanian text of any potential allusion at or connection with the political realities in Romania. This is not a translation mistake, as Bechet underlines the translator's complete involvement in the process of translation, his obsessive concern with minute details such as the number of syllables that had to match the one in the original text (Berechet, 213).Vasilescu may have understood that there was no way out and he was ready to compromise. As Boia remarks, they were giving up saying all they were thinking because they could, at least, say part of it: "Libertatea, aşa îndiguită cum era, părea un câștig extraordinar față de atmosfera de plumb a anilor 50. Iar dreptul de a afirma răspicat credința în valorile naționale apărea, în contrast cu detestabilul antinaționalism de până mai ieri, ca o prețioasă expresie de libertate (devenită repede, ce e drept, o obligație)"'(Boia, 2016:100).

What I find even more interesting, is the way in which the anectodical that surrounds the Scottish play was also localised. In Lady Macbeth in America, Gay Smith speaks of Anderson and Olivier Macbeth production in 1937 that "had its share of bad luck traditionally associated with the play" (Smith, 2010:160). In Shakespeare's Ghost Writers. Literature as Uncanny Causality, Marjorie B. Garber also enumerates a number of gloomy stories that derived from some misfortunes that scarred the English stage history of the play (Garber, 2004:90). In the same Nine Blue Notebooks, director Mihai Berechet recorded similar events that marked the Romanian stage history of Macbeth: Sava's performance was only staged 21 times, time lapse in which he got an illness that lead to his premature death, Nini Ciulei, Liviu Ciulei's sister, died during rehearsals for the same performance.

\footnotetext{
9 "Freedom, dyked as it was, seemed an extraordinary gain when compared to the leaden atmosphere of the fifties. And the right to clearly assert one's faith in the national values appeared, in contrast with the recent detestable antinationalism, as a precious expression of freedom (that quickly turned, it is true, into an obligation)" (my translation).
} 
During his own staging of the play, an extra died of food poisoning, Al. Alexandru Vrancea, playing Banquo, was announced of his mother's death and an extra of her husband's death while they were on stage, and exactly on premiere night, the urn containing the ashes of Tony Gheorghiu, the creator of the decor and costumes for the play, was brought back into the country from Sweden (Berechet, 2015). The need to culturally engulf Shakespeare's text goes beyond page and stage level, feeding on the Romanian's appetite for superstition.

To conclude, the ethnocentric tendencies in the Romanian translations of Macbeth are triggered by three factors. First and most important of all is the populist nationalist discourse and the anti-neologist movements that emerged at the end of the 19th century and continued through the first half of the $20^{\text {th }}$ century. The second is the attempt of the communist discourse to confiscate the already formulated national discourse, which, slightly altered, could serve the regime's ideological needs. Fortunately, in the case Macbeth, this is restricted to Vasilescu's text and according to Berechet it didn't even make it to the stage as the director altered the translation. The last factor derives from the stylistic needs of the translator who found the cold neological terms inappropriate for the translation of so lyrical a text. A good example in this respect is Horia Gârbea's latest translation of the play, where rare or obsolete words, such as hâd, much blamed by Botez in Stern's text ${ }^{10}$, are used with ease, proving that the Romanian language is mature enough to accomodate meanings rendered in all linguistic registers. Anthony Pym, translator and translation theorist, says that the "the main reasons for linguistic deviance must surely be the personal identity of the translator" (Pym, 1996:175).

The translation of the play should represent what Anthony Pym, called the middle term, the individual energy generally neglected by abstract theories, which means to reconcile the conflicting and mutually exclusive attitudes promoted by Lawrence Venuti's reductionist binarism (idem), revealing the "joyful and necessary interaction of personalities"11 (in Stanley Wells's words) between the author and his interpreter/translator.

\section{Works Cited}

Berechet, M. 1983. Nouă caiete albastre[Nine Blue Notebooks]. București: Editura Muzicală.

Braunmuller, A.R.(ed.). 1999. Macbeth. Cambridge University Press.

Boia, L. 2016. Strania istorie a comunismului românesc (și nefericitele ei consecințe) [The Strange History of the Romanian Communism (and its Unfortunate Consequences)]. București : Humanitas.

Boia, L. 2002. Istorie şi mit în conștiințta românească [History and Myth in Romanian Consciousness]. București : Humanitas.

Dicţionarul literaturii române de la origini până la 1900 [The Dictionary of Romanian Literature from its Origins to 1900]. 1979.București:Editura Academiei Republicii Socialiste România.

Dragomirescu, M. 1934. Sămănătorism, Poporanism, Criticism. București : Editura Noului Institut de Literatură.

Garber, M. B. 2004. Shakespeare's Ghost Writers. Literature as Uncanny Causality. London: Methuen Co. Ltd.

Hobsbawm, E. J. 2000. Nations and Nationalism since 1780. Cambridge University Press.

Lefevere, A. (ed.). 1992. History, Culture: A Sourcebook, London: Routledge.

Letourneur, P. 1778, Shakespeare traduit de l'anglois, Tome Troisième, Paris.

Morar, O. 2003. Avangarda românească în context european, Editura Universităţii Suceava.

Meyer, H. (ed). 1836. Oeuvres Dramatiques de Shakespeare, Traduites de l anglais par Letourneur, Nouvelle edition, Tome Premier. Paris: Lavigne.

Mandelbaum, D. G. (ed.). 1985. Selected Wrirings of Edward Sapir in Language, Culture and Personality. Berkeley, Los Angeles, London : University of California Press.

Pym, Anthony. 1996. "Venuti's Visibility". in Target, 8/2(1996):165-177. John Benjamins.

Petrovici, V. 1977. Macbeth cu măști: caietul unui spectacol de Ion Sava. București:EditurTehnică.

Shakespeare, W. 1850. Macbeth: dramă in quinqui acte. traducere de Ștefan Băjescu. București: Tipografia de Jos, Copainig.

Shakespeare, W. 1957. Macbeth. Traducere de Ion Vinea. București: Editura de Stat pentru Literatură și Artă.

\footnotetext{
${ }^{10}$ See my article in Messages, Sages and Ages, Vol 2, No.1, 2015.

${ }^{11}$ From Stanley Wells's speech in the plenary session of the conference Shakespeare in România, Shakespeare in lume [Shakespeare in Romania, Shakespeare in the World], Bucharest, April 2016.
} 
Shakespeare, W. 2014. Opere. Vol 9. Eduard al III-lea. Mult zgomot pentru nimic. Macbeth. (Macbeth tradus de Horia Gârbea) București:Tracus Arte.

Smith, A.D. 2003. Nationalism and Modernism: A Critical Survey of Recent Theories of Nations and Nationalism. London and New York: Routledge.

Smith, G. 2010. Lady Macbeth in America. From the Stage to the White House. New York: Palgrave Macmillan.

Venuti, L. 1995. Translator's Invisibility: A History of Translation, London: Routledge. 